\title{
Archaeal halophiles (halobacteria) from two British salt mines
}

\author{
Cynthia F. Norton, $\dagger$ Terry J. McGenity and William D. Grant* \\ Department of Microbiology, University of Leicester, Medical Sciences Building, University Road, \\ Leicester LEI $9 H N$, UK
}

(Received 14 July 1992; revised 6 January 1993; accepted 18 January 1993)

\begin{abstract}
Samples were taken from the Winsford salt mine in Cheshire, England, which exploits bedded deposits from the Triassic Period (195-225 million years ago, MYA) and from Boulby potash mine in Cleveland, England, which is Permian (225-270 MYA) and is mined for the mineral sylvite $(\mathrm{KCl})$. Halobacteria and obligately halophilic eubacteria were isolated from several different sample types. The halobacteria were characterized by chemotaxonomic methods and most but not all were shown to be very similar but not identical to those halobacterial types that dominate in highly concentrated surface brines. There was a high degree of similarity between the two mine populations, but some strains were particular to each mine.
\end{abstract}

\section{Introduction}

Archaeal halophiles (halobacteria) are a unique group of micro-organisms which make up the dominant microbial populations of hypersaline waters $(>15 \%, \mathrm{w} / \mathrm{v}, \mathrm{NaCl})$ such as salt lakes and solar salterns (Grant \& Ross, 1986; Grant \& Larsen, 1989; Tindall \& Trüper, 1986). Salt deposits are the relics of ancient hypersaline evaporitic environments now buried, crystallized from brines that presumably supported dense populations of halobacteria. We have investigated whether halobacteria could inhabit salt mines.

The rock salt mine operated by Imperial Chemical Industries (ICI) at Winsford in Cheshire, England, has many miles of underground workings formed by over a century of cutting and blasting (Longley-Cook, 1989). The current mining operation is at a depth of about $170 \mathrm{~m}$, producing halite for deicing roads. The Winsford deposit is a bedded salt of the Triassic period (195-225 MYA) though its exact age is unknown. It probably has not been deeply buried or strongly heated and retains regions of unaltered primary crystalline structure (Evans et al., 1968; Roedder, 1984). The mine's ventilation circuit includes a dewatering stage. Surface air (up to $10000 \mathrm{~m}^{3} \mathrm{~min}^{-1}$ ) is drawn through a network of disused tunnels in which water vapour condenses in shallow brine pools ( $\mathrm{pH} \mathrm{5.8-7 \cdot 0)}$ which are saturated, dark and

* Author for correspondence. Tel. (0533) 522951; fax (0533) 525030.

$\dagger$ Permanent address: Department of Biology, University of Maine at Augusta, Augusta, Maine 04330, USA.

Abbreviation: MYA, million years ago. cold $\left(13^{\circ} \mathrm{C}\right.$ on average) throughout the year. The halite of the tunnel walls is moist and covered in efflorescences of recrystallized salt. Overlaying the saliferous series is a layer of brine, which wells up to the surface in a few localities in Cheshire forming brine springs and pools.

Permian (225-270 MYA) salt is exploited at Boulby, Cleveland, England, by Cleveland Potash Ltd for the mineral sylvite $(\mathrm{KCl})$, which is used in the fertilizer industry. The Boulby mine has only been worked since 1973 and differs from the Winsford mine in many respects. It is much deeper $(1200 \mathrm{~m})$ and as a consequence is hotter $\left(40-42^{\circ} \mathrm{C}\right)$. Deep burial has led to extensive mineralogical change, though there are areas in which little alteration has taken place (Woods, 1979). Small amounts of brine present in Boulby salt mine either originate from within the salt strata or are derived from water percolating from the Upper Bunter Sandstone. There are no known surface brine pools in Cleveland.

\section{Methods}

Sampling and enrichment. At Winsford, brine and recrystallized salt sludges from the pools, wall efflorescences and moist surface crystals from tunnel walls were sampled. Halite samples were obtained from the working faces. At Boulby, various samples of halite $(\mathrm{NaCl})$ and 'potash' $(\mathrm{NaCl}$ and $\mathrm{KCl})$ were taken as well as samples from brine pools and efflorescences. In Cheshire, a surface brine pool (Lower Wych) and soil from two dry saline springs (Higher Wych and Hassall Green) were sampled. ICI also exploits the same halite formation a short distance away from Winsford at Lostock, where solution mining is used to recover $\mathrm{NaCl}$. Samples of brine brought to the surface at this site were made available for analysis.

Liquid samples were collected by pipette into sterile Universal vials. Sludges/efflorescences were removed with sterile wooden tongue depressors and collected in sterile plastic bags. These samples were taken to a laboratory separate from the area in which halophile 
Table 1. Groupings and numbers of salt mine isolates based on polar lipid analysis

Lipid abbreviations: PG, phosphatidylglycerol; PGP, phosphatidylglycerol phosphate; PGS, phosphatidylglycerol sulphate; S-DGD-1, sulphated mannosylglucosylglycerol diether; S-TGD-1, sulphated triglycosyl diether; S-TeGD, sulphated tetraglycosyl diether; TGD-2, galactosylmannosylglucosyl diether. Site/habitat abbreviations: W, Winsford; B, Boulby; $b+e$, brine and efflorescence; rs, rock salt; bi, brine injection fluid; s, surface brine pool.

\begin{tabular}{|c|c|c|c|c|c|c|c|}
\hline $\begin{array}{l}\text { Polar lipid profile and representative } \\
\text { Genus/species }\end{array}$ & $\begin{array}{l}\text { Core } \\
\text { lipid }\end{array}$ & $\begin{array}{c}W \\
b+e\end{array}$ & $\begin{array}{l}\text { W } \\
\text { rs }\end{array}$ & $\begin{array}{l}\mathrm{W} \\
\mathrm{bi}\end{array}$ & $\begin{array}{l}\mathrm{W} \\
\mathrm{s}\end{array}$ & $\begin{array}{c}B \\
b+e\end{array}$ & $\begin{array}{l}\text { B } \\
\text { rs }\end{array}$ \\
\hline $\begin{array}{l}\text { PG, PGP, PGS, S-DGD-1 } \\
H b . \text { saccharovorum }\end{array}$ & $\mathrm{C}_{20}, \mathrm{C}_{20}$ & 17 & 3 & 3 & & 2 & \\
\hline $\begin{array}{l}\text { PG, PGP, PGS, TGD-2 } \\
\text { Haloarcula spp. }\end{array}$ & $\mathrm{C}_{20}, \mathrm{C}_{20}$ & 1 & 4 & 9 & & 2 & \\
\hline $\begin{array}{l}\text { PG, PGP, PGS, S-TGD-1, S-TeGD } \\
\text { Hb. salinarium }\end{array}$ & $\mathrm{C}_{20} \mathrm{C}_{20}$ & 2 & & & & 1 & \\
\hline $\begin{array}{l}\text { PG, PGP, S-DGD-1 } \\
\text { Halococcus spp. }\end{array}$ & $\begin{array}{l}\mathrm{C}_{20}, \mathrm{C}_{20} \\
\mathrm{C}_{20}, \mathrm{C}_{25}\end{array}$ & & & 1 & 2 & & \\
\hline $\begin{array}{l}\text { PG, PGP, PGS } \\
\text { Profile i }\end{array}$ & $\mathrm{C}_{20}, \mathrm{C}_{20}$ & 4 & & & & & \\
\hline $\begin{array}{l}\text { PG, PGP, PGS } \\
\text { Profile ii }\end{array}$ & $\begin{array}{l}\mathrm{C}_{20}, \mathrm{C}_{20} \\
\mathrm{C}_{20}, \mathrm{C}_{25}\end{array}$ & & & & & 2 & \\
\hline $\begin{array}{l}\text { PG, PGP, unidentified glycolipid } \\
\text { Profile iii }\end{array}$ & $\mathrm{C}_{20}, \mathrm{C}_{20}$ & & & & & & 1 \\
\hline
\end{tabular}

research is normally carried out, and enrichment cultures and viable counts were performed using a $3.5 \mathrm{M}-\mathrm{NaCl}$ medium (Norton \& Grant, 1988).

Small fragments (2-5g) of rock salt newly exposed by blasting were selected and dropped into vials of absolute alcohol for surface decontamination and transport to the laboratory $(4-5 \mathrm{~h})$. The salt fragments were then transferred aseptically to Universal vials containing $10 \mathrm{ml}$ enrichment broth and incubated with shaking at $37^{\circ} \mathrm{C}$ for 2-3 weeks.

The efficacy of the surface sterilization procedure was established by incorporating orange-pigmented halobacteria into halite crystals, placing $4-5 \mathrm{~mm}$ crystals into thick suspensions of pink-pigmented halobacteria in growth medium containing $4.5 \mathrm{M}-\mathrm{NaCl}$ for $4 \mathrm{~h}$ and then transferring these crystals to vials of absolute alcohol (Norton \& Grant, 1988). Experiments were also carried out with crystals sterilized overnight at $160^{\circ} \mathrm{C}$. Following immersion in ethanol for $2 \mathrm{~h}$, only unheated crystals yielded halobacteria and these halobacteria were orange-pigmented.

Polar lipid analysis. Phospholipids and glycolipids were isolated and characterized by standard methods (Lanzotti et al., 1988, 1989; Ross et al., 1985).

DNA hybridization. Early stationary-phase cells (5-6 g wet wt) were suspended in $5 \mathrm{ml} 25 \%(\mathrm{w} / \mathrm{v}) \mathrm{NaCl}$ containing $2 \% \mathrm{MgSO}_{4} .7 \mathrm{H}_{2} \mathrm{O}$ at $4{ }^{\circ} \mathrm{C}$ and lysed by addition of $0.5 \mathrm{ml} 2 \%(\mathrm{w} / \mathrm{v})$ sodium deoxycholate. DNA was extracted with TE-saturated phenol, spooled on glass rods, and treated with ribonuclease (Boehringer) and proteinase $\mathrm{K}$ as described by Tindall et al. (1984). DNA:DNA homologies were determined using a modified S1 nuclease method (Crosa et al., 1979; Tindall et al., 1984) and nick-translation (Amersham). Hybridizations were carried out at $67^{\circ} \mathrm{C}$ for $16 \mathrm{~h}$.

\section{Results and Discussion}

Spreads of brines and moist salts diluted/dissolved in media produced diverse populations after incubation at $37^{\circ} \mathrm{C}$ for $2-3$ weeks. Colonies were presumed halo- bacteria if they had red bacterioruberin pigmentation or eubacteria if white or cream coloured. These assignments were confirmed by lipid analyses (Ross et al., 1985). Eubacteria predominated in brine pools at Winsford mine $(80-90 \%$ of colonies in viable counts) and in surface sites, while mine efflorescences and other moist salts from Winsford had roughly equal numbers of both types. Solution mining brine from Lostock yielded only halobacteria, as did all Boulby samples. Enrichments from all of these sites in liquid media invariably became dominated by halobacteria. Viable counts of Winsford brines ranged from $5 \times 10^{5}$ to $2 \times 10^{6}$ c.f.u. $\mathrm{ml}^{-1}$. Efflorescences and moist salts yielded $4 \times 10^{4}$ to $4 \times 10^{5}$ c.f.u. $\mathrm{g}^{-1}$. Plates incubated at $12^{\circ} \mathrm{C}$ produced similar counts after a longer incubation (3-4 months). Viable counts of Boulby brines ranged from $2 \times 10^{2}$ to $5 \times 10^{6}$ c.f.u. $\mathrm{ml}^{-1}$ depending on site, and Lostock solution mining brine yielded $2.7 \times 10^{3}$ c.f.u. $\mathrm{ml}^{-1}$.

With the exception of isolates resembling Halococcus spp., all strains tested required at least $1.7 \mathrm{M}-\mathrm{NaCl}$ for growth, most needing a minimum of $2.6 \mathrm{M}-\mathrm{NaCl}$ in the medium.

Forty-six red colonies were randomly selected from spreads of Winsford and Boulby brine pools and efflorescences, Lostock solution mining brine and surface brine pools. In addition, rock salt enrichments gave rise to seven red isolates from Winsford and one from Boulby, with approximately one positive enrichment per $500 \mathrm{~g}$ of rock salt inoculum (Table 1).

Halobacteria are currently classified into six genera and three other unnamed groups based on polar lipid patterns (Grant \& Larsen, 1989). Polar lipid analysis 

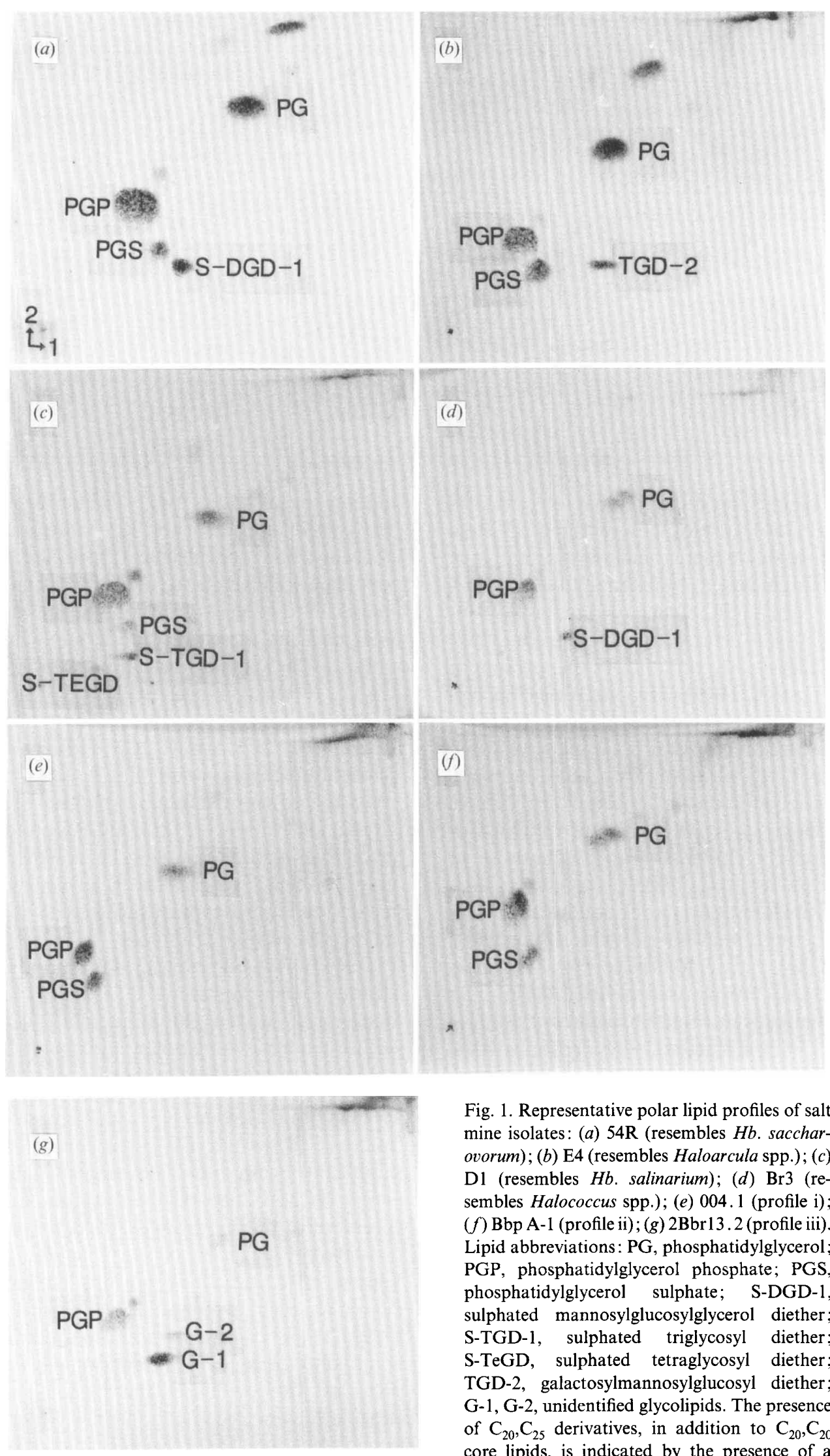

Fig. 1. Representative polar lipid profiles of salt mine isolates: (a) 54R (resembles $H b$. saccharovorum); (b) E4 (resembles Haloarcula spp.); (c) Dl (resembles $H b$. salinarium); (d) $\mathrm{Br} 3$ (resembles Halococcus spp.); (e) 004.1 (profile i); $(f)$ Bbp A-1 (profile ii); $(g)$ 2Bbr13.2 (profile iii). Lipid abbreviations: PG, phosphatidylglycerol; PGP, phosphatidylglycerol phosphate; PGS, phosphatidylglycerol sulphate; S-DGD-1, sulphated mannosylglucosylglycerol diether; S-TGD-1, sulphated triglycosyl diether; S-TeGD, sulphated tetraglycosyl diether; TGD-2, galactosylmannosylglucosyl diether; G-1, G-2, unidentified glycolipids. The presence of $\mathrm{C}_{20}, \mathrm{C}_{25}$ derivatives, in addition to $\mathrm{C}_{20}, \mathrm{C}_{20}$ core lipids, is indicated by the presence of a double-spot PG. The lipids were run in two dimensions as indicated by the arrows, using the method of Ross et al. (1985). 
Table 2. DNA:DNA homologies of Cheshire isolates

\begin{tabular}{|c|c|c|c|c|c|}
\hline \multirow[b]{2}{*}{ Organism } & \multirow[b]{2}{*}{ Origin } & \multirow[b]{2}{*}{ Lipid profile } & \multicolumn{3}{|c|}{$\begin{array}{l}\text { Percentage DNA binding with } \mathrm{H}^{3} \text {-labelled } \\
\text { DNA from: }\end{array}$} \\
\hline & & & $\begin{array}{l}\text { Halobacterium } \\
\text { saccharovorum } \\
\text { NCMB } 2081\end{array}$ & $\begin{array}{l}\text { Halobacterium } \\
\text { salinarium } \\
\text { CCM } 2090\end{array}$ & $\begin{array}{c}\text { Haloarcula } \\
\text { vallismortis } \\
\text { ATCC } 29715\end{array}$ \\
\hline H. saccharovorum & San Francisco saltern & PG, PGP, PGS, S-DGD-1 & 100 & 11 & 17 \\
\hline 008.1 & Winsford brine & PG, PGP, PGS, S-DGD-1 & 53 & 17 & 15 \\
\hline $54 \mathrm{R}$ & Winsford rock salt & PG, PGP, PGS, S-DGD-1 & 48 & 12 & 19 \\
\hline E9 & Winsford effiorescence & PG, PGP, PGS, S-DGD-1 & 31 & 19 & 21 \\
\hline H. vallismortis & Death valley pool & PG, PGP, PGS, TGD-2 & 21 & 20 & 100 \\
\hline E4 & Winsford rock salt & PG, PGP, PGS, TGD-2 & 13 & 12 & 30 \\
\hline Brine 1 & Lostock solution mining brine & PG, PGP, PGS, TGD-2 & 12 & 13 & 46 \\
\hline H. salinarium & Salted hides & $\begin{array}{l}\text { PG, PGP, PGS, S-TGD-1, } \\
\text { S-TeGD }\end{array}$ & 18 & 100 & 24 \\
\hline D1 & Winsford brine & $\begin{array}{l}\text { PG, PGP, PGS, S-TGD-1, } \\
\text { S-TeGD }\end{array}$ & 19 & 40 & 15 \\
\hline
\end{tabular}

(Table 1, Fig. 1) placed the mine halobacteria isolates common to both mines as biotypes in three of these nine groups. Twenty-five isolates, including three rock salt isolates, resemble the organism Halobacterium saccharovorum NCMB 2081 which is currently considered a species incertae sedis (Grant \& Larsen, 1989) and was originally isolated from a San Francisco saltern (Tomlinson \& Hochstein, 1976). TLC analyses (Fig. 1a) indicate that these possess diphytanyl $\left(\mathrm{C}_{20}, \mathrm{C}_{20}\right)$ derivatives of phosphatidylglycerol (PG), phosphatidylglycerol phosphate (PGP), phosphatidylglycerol sulphate (PGS) and a sulphated mannosylglucosylglycerol diether (S-DGD-1) (Lanzotti et al., 1988). The polar lipids of this group of strains co-chromatograph with those of H. saccharovorum (Ross et al., 1985).

Sixteen isolates, including four rock salt strains, have polar lipids that co-chromatograph with lipids from representatives of the genus Haloarcula (Fig. $1 b$ ). These isolates possess $\mathrm{C}_{20}, \mathrm{C}_{20}$ derivatives of $\mathrm{PG}, \mathrm{PGP}, \mathrm{PGS}$ and a characteristic galactosylmannosylglucosylglycerol diether (TGD-2) (Grant \& Larsen, 1989). Three isolates, all derived from brines or brine salt sludges, have polar lipids identical to those of Halobacterium salinarium CCM 2090 (Fig. 1c). These isolates have $\mathrm{C}_{20}, \mathrm{C}_{20}$ derivatives of PG, PGP, PGS, a sulphated galactosylmannosylglucosylglycerol diether (S-TGD-1) and a sulphated tetraglycosylglycerol diether (S-TeGD) (Grant \& Larsen, 1989). These mine halobacteria are typical of the halobacteria that become dominant near saturation in salterns and the relative frequency of isolation of these types matches that reported in saturated salterns (Rodriguez-Valera et al., 1985).

Isolates with characteristic coccoid morphologies and polar lipid patterns typical of Halococcus spp. $\left(\mathrm{C}_{20}, \mathrm{C}_{20}\right.$ and $\mathrm{C}_{20}, \mathrm{C}_{25}$ derivatives of PG, PGP, TGD-2 and SDGD-1) were found in surface brine pools and solution mining brine (Fig. 1d). Unlike other halobacteria, Halococcus spp. are able to withstand the lower salt concentrations (Rodriguez-Valera et al., 1979) that would periodically be typical of these particular environments. No other types of halobacteria have yet been isolated from the surface brine pools in Cheshire.

Particular to Winsford mine were four isolates with $\mathrm{C}_{20}, \mathrm{C}_{20}$ derivatives of $\mathrm{PG}, \mathrm{PGP}$ and $\mathrm{PGS}$ and no glycolipids (profile i) (Fig. 1e). Two isolates from Boulby had both $\mathrm{C}_{20}, \mathrm{C}_{20}$ and $\mathrm{C}_{20}, \mathrm{C}_{25}$ derivatives of these three phospholipids (profile ii) (Fig. $1 f$ ). An additional strain was isolated from a Boulby 'potash' sample which had $\mathrm{C}_{20}, \mathrm{C}_{20}$ derivatives of PG, PGP and two unidentified glycolipids (profile iii) (Fig. $1 \mathrm{~g}$ ). To date, these polar lipid profiles have not been described for any halobacterium from a typical surface site such as a salt lake or solar saltern.

DNA:DNA homology studies on a small number of strains from Winsford (Table 2) indicate limited homologies between salt mine isolates and representative strains from the same polar lipid group. These homology values are comparable to those used to define a different species within a group (Ross \& Grant, 1985). In addition, isolate $54 \mathrm{R}$, a saccharovorum type, does not react significantly with antisera prepared against $H$. saccharovorum NCMB 2081 (E. Conway de Macario, personal communication; Conway de Macario et al., 1986a,b).

There are early reports of bacteria recovered from mineral salt and brine springs (Dombrowski, 1963; Reiser \& Tasch, 1960), published before the halobacteria were recognized as a specific taxonomic group highly adapted to the hypersaline environment. Careful reading provides no evidence that organisms other than eubacteria were recovered in these experiments and it is difficult to rigorously exclude the possibility of contamination by ubiquitous halotolerant surface types. 
Our work differs from that of previous investigators in documenting a substantial and obligately halophilic bacterial flora in situ. There are two tenable hypotheses to explain the source of these bacterial populations, particularly the halobacterial population-either the organisms have been introduced from surface sources, or they are the descendants of an ancient population entrapped when the beds were formed.

Salt has been mined at Winsford since 1844 and at Boulby since 1973, and it is arguable that halobacteria in the mines are not a consequence of contamination, because there has been no typical surface environment for halobacteria in North Europe in recent geological time and halobacteria, except Halococcus spp., rapidly lose viability in growth media containing less than $1.5 \mathrm{M}$ $\mathrm{NaCl}$. Small crystals of wind-blow salt containing viable halobacteria could conceivably have seeded the mines, but the wide diversity of halobacteria isolated, together with the recent opening of Boulby mine, makes this less than certain.

We have previously established that halobacteria become entrapped within the fluid inclusions of salt crystals grown in vitro, surviving for several years (Norton \& Grant, 1988). Cells are also commonly visible within fluid inclusions in salt crystals formed in salterns and salt lakes (Norton \& Grant, 1988). These observations provide a conceptual basis with which to understand our finding that viable halobacteria are to be found with rarity within halite crystals from the salt deposits. The organisms in the brine pools may thus be derived from the rock salt, or vice versa.

We believe that the long-term survival of populations originally entrapped when the salts formed 200 or 230 million years ago is at least a tenable hypothesis for the presence of these archaea within the mines. We are not in a position to answer the profoundly interesting question of what roles processes such as very slow growth rates and/or extremely long dormancy periods might contribute to long-term survival.

The authors wish to thank G. Pinch, J. Maley and C. Edwards for technical assistance, ICI and Cleveland Potash Ltd for providing access to the mines for salt and brine samples, and the University of Maine for travel support.

\section{References}

Conway de Macario, E., Konig, H. \& Macario, A. J. L. (1986a). Immunologic distinctiveness of archaeobacteria that grow in high salt. Journal of Bacteriology 168, 425-427.
Conway de Macario, E., Macario, A. J. L. \& Jovell, R. J. (1986b). Slide immunoenzyme assay (SIA) in hybridoma technology. Methods in Enzymology 121, 509-525.

Crosa, J. H., Williams, B. L., Jorgensen, J. J. \& Evans, C. A. (1979). Comparative study of deoxyribonucleic acid homology and physiological characteristics of strains of Peptococcus saccharolyticus. International Journal of Systematic Bacteriology 29, 328-332.

DombrowsKi, H. J. (1963). Bacteria from palaeozic salt deposits. Annals of the New York Academy of Sciences 108, 453-460.

Evans, W. B., Wilson, A. A., Taylor, B. J. \& Price, D. (1968). Geology of the country around Macclesfield, Congleton, Crewe and Middlewich (Sheet 110). Memoir of the Geological Survey UK. London: HMSO

Grant, W. D. \& LARSEN, H. (1989). Extremely halophilic archaeobacteria. Order Halobacteriales ord. nov. In Bergey's Manual of Systematic Bacteriology, vol. 3, pp. 2216-2233. Edited by J. T. Staley, M. P. Bryant, N. Pfennig \& J. G. Holt. Baltimore: Williams $\&$ Wilkins.

Grant, W. D. \& Ross, H. N. M. (1986). The ecology and taxonomy of halobacteria. FEMS Microbiology Reviews 39, 9-15.

Lanzotti, V., Nicolaus, B., Trincone, A. \& Grant, W. D. (1988). The glycolipid of Halobacterium saccharovorum. FEMS Microbiology Letters 55, 223-228.

Lanzotti, V., Nicolaus, B., Trincone, A., De Rosa, M., Grant, W. D. \& GambacorTA, A. (1989). A complex lipid with a cyclic phosphate from the archaeobacterium Natronococcus occultus. Biochimica et Biophysica Acta 1001, 31-34.

LONGLEY-COOK, W. A. (1989). Recent developments at Winsford salt mine, Cheshire, England. Transactions of the Institution of Mining and Metallurgy (Section A: Mining Industry) 98, 463-468.

Norton, C. F. \& GRANT, W. D. (1988). Survival of halobacteria within fluid inclusions in salt crystals. Journal of General Microbiology 134, 1365-1373.

REISER, R. \& TASCH, P. (1960). Investigation of the viability of osmophile bacteria of great geological age. Transactions of the Kansas Academy of Sciences 60, 31-34.

RODRIGUEZ-VALERA, F., RUIZ-BerRaquero, F. \& RAMOSCORMENZANA, A. (1979). Isolation of extreme halophiles from seawater. Applied and Environmental Microbiology 38, 164-165.

Rodriguez-VAlera, F., Ventosa, A., Juez, G. \& IMHOFF, J. F. (1985). Variation of environmental features and microbial populations with salt concentrations in a multi-pond saltern. Microbial Ecology 11, $107-115$.

ROEDDER, E. (1984). The fluids in salt. American Mineralogist 69, 413439.

Ross, H. N. M. \& Grant, W. D. (1985). Nucleic acid studies on halophilic archaebacteria. Journal of General Microbiology 131, $165-173$.

Ross, H. N. M., Grant, W. D. \& Harris, J. E. (1985). Lipids in archaebacterial taxonomy. In Chemical Methods in Bacterial Systematics, pp. 289-299. Edited by M. Goodfellow \& D. E. Minnikin. New York: Academic Press.

Tindall, B. N. J., Ross, H. N. M. \& Grant, W. D. (1984). Natronobacterium gen. nov. and Natronococcus gen. nov., two new genera of haloalkaliphilic archaebacteria. Systematic and Applied Microbiology 5, 41-57.

TINDAll, B. J. \& TRÜPER, H. (1986). Ecophysiology of the aerobic halophilic archaebacteria. Systematic and Applied Microbiology 7, 202-212.

Tomlinson, G. A. \& Hochstein, L. I. (1976). Halobacterium saccharovorum sp. nov., a carbohydrate metabolizing extremely halophilic bacterium. Canadian Journal of Microbiology 22, 587-591.

Woods, P. J. E. (1979). The geology of Boulby mine. Economic Geology 74, 409-418. 